Vol. 16, $n^{\circ} 1 \mid 2012$

Varia

\title{
Martin J. Wiener, An Empire on Trial ; Race, Murder, and Justice under British Rule, 1870-1935
}

Cambridge University Press, 2009, ISBN 978-0-521-73507-6.

\section{Georgina Sinclair}

\section{(2) OpenEdition}

\section{Journals}

Electronic version

URL: https://journals.openedition.org/chs/1341

DOI: $10.4000 /$ chs. 1341

ISSN: 1663-4837

Publisher

Librairie Droz

Printed version

Date of publication: 1 May 2012

Number of pages: 131-134

ISBN: 978-2-600-01594-3

ISSN: $1422-0857$

\section{Electronic reference}

Georgina Sinclair, "Martin J. Wiener, An Empire on Trial; Race, Murder, and Justice under British Rule, 1870-1935", Crime, Histoire \& Sociétés / Crime, History \& Societies [Online], Vol. 16, n¹ | 2012, Online since 12 March 2013, connection on 23 March 2022. URL: http://journals.openedition.org/chs/1341 ; DOI: https://doi.org/10.4000/chs.1341

This text was automatically generated on 23 March 2022.

(C) Droz 


\title{
Martin J. Wiener, An Empire on Trial ; Race, Murder, and Justice under British Rule, 1870-1935
}

Cambridge University Press, 2009, ISBN 978-0-521-73507-6.

\author{
Georgina Sinclair
}

\section{REFERENCES}

Martin J. Wiener, An Empire on Trial ; Race, Murder, and Justice under British Rule, 1870-1935, Cambridge University Press, 2009, ISBN 978-0-521-73507-6.

1 Law in the British Empire had many faces. It could prove useful to the British in helping to further colonial rule but could also be a resource with which the 'colonised' could openly criticise that rule. In An Empire on Trial, Martin Wiener reveals the British Empire to be 'a deeply contested enterprise'. This he does by exploring the issue of interracial homicide through numerous cases and their subsequent prosecution. Wiener approaches this question transterritorially during the heyday of empire at a time when the criminal justice system reached something of a watershed. As a greater system of legal fairplay was extended across the racial boundaries so the contradictions of British law were exposed and the Empire itself was 'put on trial'. At the core of this excellent book lies the premise that the British Empire was a hugely complex racial hierarchy where 'private violence' was never far from the surface of imperial life.

2 Law lay at the heart of the British Empire and the criminal justice system was embedded within that law. This resulted in the legal 'colonisation' of large parts of the non-European world possibly resulting in one of the most durable effects of imperialism. An Empire on Trial looks broadly at the consequences of the collision between the spread of British liberal ideas and the authoritarian nature of empire within the legal arena. This contest may initially have been unequal but as Wiener 
demonstrates, the increased tensions and fissures that occurred resulted in a fragmentation of the over-riding coerciveness of British imperialism.

3 Wiener begins by exploring criminal justice on 'the high seas' (the merchant fleet) which provided an early testing ground for the rule of law beyond Britain. By the 1880 's, the 'law of the sea' was replaced by rule of law as practiced on the mainland; the last authenticated flogging at sea took place, for example, during this period. Here Wiener begins to question how law intervened with the hegemony of racism at sea; Britain's maritime personnel had become increasingly multi ethnic. He shows how the lines between 'legitimate force' and 'illegitimate violence' were being reshaped and the extent to which the question of race weighed heavily upon criminal justice. The practical application of law within the criminal justice system in relation to race is constantly revisited throughout this book. In turning to Queensland, Wiener considers the 'colour line' of this self-governing colony with its unusual mix of whites, Aborigines, Pacific Islanders and Chinese. In contrast to the previous chapter, Wiener moves to the colonial courtroom, painting a picture of a colony where British imperial authority was at its weakest. Queensland politics were complex and subjected to pressures from local people as well as a constant influx of settlers, labourers, missionaries and so on, who became typically hostile to any interference from the imperial government. From 1869 to 1872, Queensland's homicide trials alerted the public to the continuing potential for violence often provoked by 'unabashed racism'. This was though a time of social change. The Pacific Islanders Protection Act of 1872 and the creation of the Western Pacific High Commission in 1877 provided an imperial framework to regulate the recruitment of potential workers : the 'kidnap' of islanders for labour purposes was by then outlawed, serious crimes committed by recruiters against workers would be prosecuted, which would result in the establishment of a different social order where "law" could come into its own'.

The British Empire was invigorated by the global movement of people, a theme considered in the 'new' crown colony Fiji. Here Wiener delves into the manner in which the political dynamics of a colony could be shaped by an individual, and the legal machinery changed as a result. Arthur Gordon, who became the Governor of Fiji in 1875, 'experimented' in protecting indigenous Fijians from settler domination, an 'early building block' Wiener argues, of the system of indirect rule. Backed by Whitehall, Gordon (the youngest son of the former Prime Minister Lord Aberdeen and previous Governor of Mauritius), literally 'laid down the law' to planters, labour recruiters and other settlers who sought political and social domination. Gordon's goal was to prevent Europeans from excessive freedom of enterprise whilst imposing their own personal rights over and above indigenous people. This concept was extended to the courts where settler racism no longer prevailed. In Trinidad and the Bahamas these social problems are also captured; a colony that traditionally imported indentured labour from India to harness the power of the sugar plantations. By the 1880's there were, Wiener notes, 134,000 of these 'coolie settlers' (many Indians did not want to return home) who were deemed inferior (in a manner reminiscent of Fiji) by European planters. Here again Wiener demonstrates how the social and legal fabric of a colony could be altered by an individual. In this case one Henry Blake, who became governor of the Bahamas in 1884, tackled what he saw as 'sluggish government' and oldfashioned administration of justice based on the eighteenth century principle of unpaid resident magistrates. Blake pushed through new legislation in 1886 to create salaried legal officers - Stipendiary and Circuit Magistrates - who would travel around the 
outlying islands to hear appeals against the decision of the resident Justices. In essence Blake hoped this would contribute to tackling what he perceived as ongoing social injustice in failing to bring issues of 'private violence' to the fore.

5 In India, 'private violence' had always been commonplace : many cases of violent death perpetrated by Europeans never reached the criminal courts ; between 1880 and 1900, only 81 shooting 'accidents' were recorded in which Europeans were responsible for the death of Indians. Indeed criminal trials even for fatalities were the exception and a conviction typically resulted only in a fine. Yet India by this period was undergoing its own social transformation with the advent of the India Office in 1888 and the increase in Indian lawyers and newspaper editors keen to use the criminal justice system as a mechanism by which political struggles could be continued. Wiener devotes two chapters to the Indian legal arena revealing the difficulties the British faced in extending liberalism at the turn of the twentieth century. The Indian Penal Code had been shaped on British criminal law with the bonus of having been 'cleansed of many technicalities and obscurities that had accumulated over the centuries'. The 1872 Criminal Procedure and Evidence Acts contained provisions that both favoured and restrained state power, though crucially the code differed in being less severe on acts of violence and thus it became more legally onerous than in England, to convict anyone of the capital offence of murder or manslaughter. As Wiener notes 'the laxity of justice when Indians were killed by Europeans was in contrast to the excessive vigour when, as happened more rarely, a European was killed'. And yet in response to new legislation, as the cases here demonstrate, most convictions that carried the death penalty, whether they involved Indians or Europeans, were overturned on appeal. Wiener describes clearly how criminal justice in British India (as with other parts of the Empire) was hugely political, responding to the array of social tensions that existed between the metropole (Whitehall), the periphery (Indian Civil Service) and a growing Indian intelligentsia who more often than not were opposed to the viewpoint of the European community.

6 Interracial struggles contributed to the legal clashes that resulted from Kenya's mix of European settlers, British officials, local people, and a growing number of Indian migrants. Kenya, unlike many of the 'older' colonies, had a growing - rather than shrinking - white population at the turn of the twentieth century who aspired to building a 'white man's country' in Africa. The homicide trials discussed involved European farmers, drawing parallels with previous case studies, and the struggle between land owners and indigenous workers as well as a growing quest for legal justice. The initial Kenyan High Court trial in 1905 of the first two convictions of white men for the murder of Africans provoked furious public debates regarding the right to a fair trial (by jury) and the composition of the jury itself. Typically 'white witnesses' did not come forward if fellow Europeans were implicated in serious crimes. The 'Wehner' case became something of a cause célèbre (in the event his sentence was commuted to penal servitude at appeal) in harnessing the indignation of settlers towards their perception of injustice towards their fellow colonists. This contributed to the rising political tensions between the metropole and the periphery over settler hegemony which would result in a bitter and bloody chapter at end of empire.

7 Yet in a slightly different vein, the attempts to extend liberalism to empire within the criminal justice system encountered the potential for a diplomatic clash. In a final chapter, Wiener uncovers the case of an American citizen, Thurman Gantt, who stood 
trial for murder in British Honduras in 1934. (Gantt was originally from Alabama and had come to the colony to set up a lumber mill business where he had killed a local man that he believed to have stolen from him.) This 'special situation' of an American on trial for murder, and subsequently convicted, led to the involvement of both governments. Following the trial, the US State Department asked the American Embassy in London to intervene on their behalf and negotiate with the Foreign Office, who then turned to the Colonial Office. (US officials had requested that Gantt should be deported to an American prison). After much diplomatic wrangling, the Foreign office was advised to tell the US that they had no 'power to order a retrial or to interfere with the verdict in this case'. In exploring the Gantt case, Wiener demonstrates how colonial justice was not only shaped by racial and social issues but also its gradual disintegration and rebuilding of a new order. By the 1930's, the old racial hierarchy was being challenged, no longer shielded by the criminal justice system and, equal justice before the law became paramount. It was telling in Gantt's case that despite US pressure upon Whitehall, the then Governor Burns refused their demands for his early release from prison, and whilst far shorter than previously intended, kept Gantt in Belize for a further $2 \frac{1}{2}$ years prior to his early release.

8 An Empire on Trial takes the reader on a fascinating journey to the heart of the relationship between liberalism and empire challenging the notion that empire was either a cause 'for celebration or indictment'. The British Empire, as these interracial trials, convictions and courtroom struggles reveal was a vast melting pot of many different 'imperial projects'. Wiener's profound understanding of criminal law and his meticulous attention to detail has made this book an extremely important contribution to imperial and commonwealth history and legal history. If there is a criticism to be made then this book left the reader wanting to know more about other quarters of Empire: there is only one reference to British Colonial Africa (Kenya) and no case studies drawn from Southeast Asia, the Middle East and the Mediterranean. Moreover, it is now recognised that the empire had as great an impact upon the metropole as the metropole had upon empire. If rule of law, and by extension the criminal justice system, has remained one of the more positive legacies of empire and commonwealth then what of the impact upon the English legal system of the imperial experiences of law? Martin Wiener has provided the starting point and a real opportunity for further study and debate within this area.

\section{AUTHORS}

\section{GEORGINA SINCLAIR}

The Open University

g.s.sinclair@open.ac.uk 